\title{
Southwest Geographic Science Team
}

The U.S. Geological Survey (USGS)

Southwest Geographic Science Team (SGST) was established in October 2001. The mission of the SGST is to establish and implement National Mapping Discipline (NMD) activities in Arizona, Utah, Nevada, and Southern California. The SGST focuses on studies and data collection in the Mojave and Sonoran Deserts, the Colorado Plateau, and the Great Basin. Studies encompass activities in all three NMD programs--Cooperative Topographic Mapping, Land Remote Sensing, and Geographic Analysis and Monitoring--as well as interdisciplinary studies with other USGS programs.

The SGST currently has personnel in three locations: Tucson, Ariz.; Flagstaff, Ariz.; and Salt Lake City, Utah. Staff will continue to increase in these and/or other locations as the SGST program grows.

\section{Tucson Office}

The Tucson office currently consists of the Chief, SGST, and a small but growing staff. The office, housed on the campus of the University of Arizona, is collocated with USGS scientists from the other disciplines (that is, geology, biology, and hydrology). Although staff may work on projects anywhere, the primary focus of the projects will be on the Desert Southwest and the United States/Mexican border. One current project is participation in the interdisciplinary USGS Mojave
Desert Ecosystem Initiative entitled

"Recoverability and Vulnerability of Desert Ecosystems." This project is assessing the vulnerability of deserts to various disturbances, such as the off-road vehicle use shown in the figure below, and the potential for short- and long-term recoverability based on the physical and biological characteristics.

The functions of the NMD State liaison for the States of Arizona and Nevada (currently handled through Menlo Park, Calif.) will also become the responsibility of the SGST. The NMD State liaisons work with State, Federal, and local organizations to coordinate geospatial data development and maintenance for the State. The best location for these two liaison functions within the SGST areas will be determined.

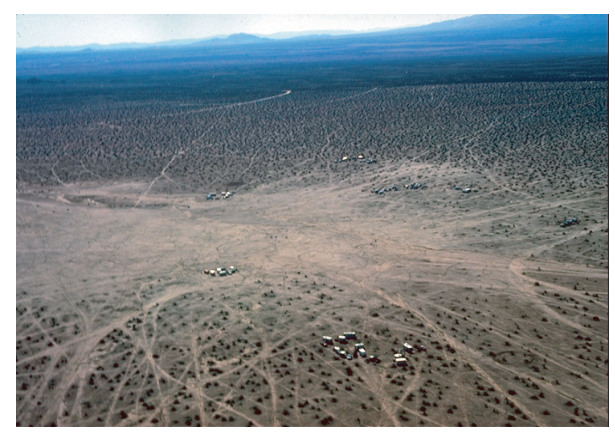

Off-road vehicle use in the Mojave Desert (USGS photo).

\section{Flagstaff Office}

The Flagstaff office is collocated with the other USGS disciplines at the USGS Flagstaff Field Center. The SGST staff has expertise and extensive experience in a variety of technologies, including the image processing of multispectral satellite and airborne imagery, geospatial analysis, the use of digital map products and GISs to produce specialized map products, and the design, development, and implementation of Oracle databases and associated Web interfaces. Project activities are primarily focused on the Southwestern United States and the Colorado Plateau, but often project activities extend throughout the United States and occasionally into international environments.

The following are examples of some of the projects conducted by the Flagstaff office:

- Image processing of various areas in the Southwestern United States; for example, Landsat thematic mapper image mosaics of the following: (1) the State of Arizona for the Arizona Geographic Information Council (see figure below), (2) the Grand Canyon for Grand Canyon National Park, and (3) the State of New Mexico for USGS geologists

- Support for the Western Region Coastal and Marine Geology Team in processing digital imagery of coral reefs in Hawai'i 
- Design and development of the National Geologic Map Databases, in support of the National Cooperative Geologic Mapping Program, including designing and developing the internal Oracle database structure, developing search mechanisms and Web interfaces, data loading, and enhancing database functionality - Cooperative projects with the Arizona Game and Fish Department to develop and publish a series of shaded-relief maps of all Game Management Units in the State.

\section{Salt Lake City}

The SGST has one person in Salt Lake City who is the NMD liaison for the State of Utah, as well as the NMD liaison to the U.S. Forest Service (FS), and is located in the FS Geospatial Service and Technology Center (GSTC). The Salt Lake City office supports the SGST activities in Utah by working closely with the Utah Automated Geographic Reference Center (AGRC) to coordinate the development and maintenance of geospatial data for the State. One current project is The National Map Utah Transportation Pilot Project, which is a collaborative USGS/AGRC effort to assemble, develop, and integrate vector transportation datasets in one urban and one rural county. This project, along with other National Map pilots, is developing the processes and techniques that will be needed in achieving nationwide coverage by The National Map.

The GSTC is the national location for geospatial activities for the FS. The USGS has interagency data-sharing agreements with the FS for

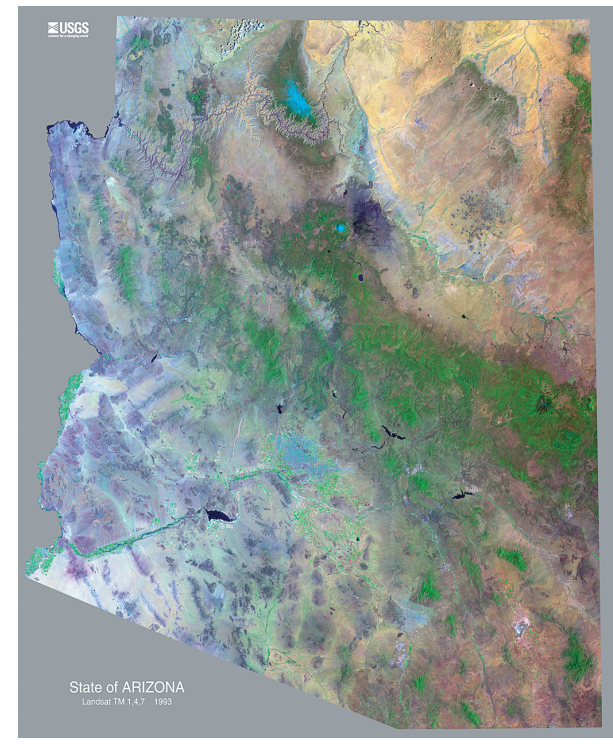

Landsat thematic mapper satellite image mosaic of Arizona produced for the Arizona Geographic Information Council.

orthoimagery, elevation data, and topographic mapping (or the "SingleEdition Program," which is a collaborative USGS/FS effort to jointly revise 1:24,000-scale topographic maps containing National Forest System lands). The SGST Salt Lake City office is responsible for coordinating these efforts, as well as other joint programs, such as the Forest Visitor Map Program.

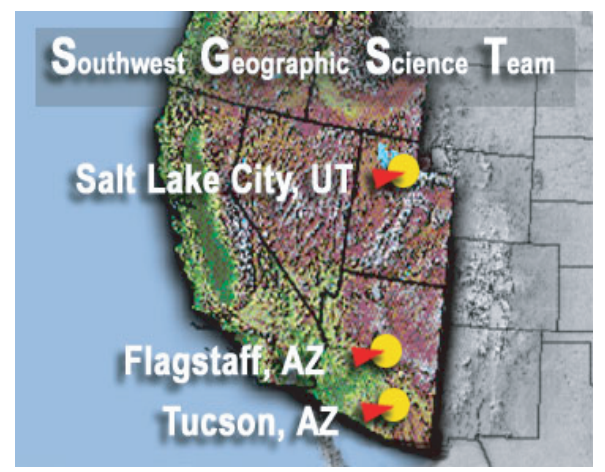

Locations of SGST offices.
More Information about the USGS Southwest Geographic Science Team

Ann Frazier

U.S. Geological Survey 520 N. Park Avenue, Rm. 106

Tucson, AZ 85719-5035

Phone: 520-670-5019

E-mail: afrazier@usgs.gov

\section{Additional Information}

USGS State Representative 520 N. Park Avenue, Suite 221

Tucson, AZ 85719-5035

Phone: 520-670-6671, ext. 221

FAX: 520-670-5592

\section{USGS Home Page}

www.usgs.gov

\section{Reports and products 1-888-ASK-USGS}

